\title{
The Impact of Social Media on Mental Health of Under Graduate Students of Nadia District in West Bengal During Covid-19 Pandemic
}

\author{
Santu Biswas ${ }^{1, *} \&$ Dibyendu Bhattacharyya ${ }^{2}$ \\ ${ }^{1}$ Dwijendralal College, Krishnagar, West Bengal, India \\ ${ }^{2}$ University of Kalyani, West Bengal, India \\ *Corresponding author: Dwijendralal College, Krishnagar, West Bengal, India. E-mail: santubiswas031@gmail.com
}

Received: September 20, 2020 Accepted: March 8, 2021 Online Published: July 18, 2021

doi:10.5430/wjss.v8n2p32 URL: https://doi.org/10.5430/wjss.v8n2p32

\begin{abstract}
The world is going through panic, fear, anxiety, stress, worry and isolation because of COVID 19 pandemic and lockdown. Almost one third of the world population is living under some kind of quarantine or lockdown. All these things affect the mental health of any individual a lot. At this time of social distancing and self-isolation, social media can be an indispensible tool for keeping you in touch with friends, online class, loved ones and the wider world. But be mindful of how it makes you feels. If spending time on social media enhance your stress, anxiety, and uncertainty, takes steps to limit your engagements. And always check reputable news sources before believing-or forwarding - any rumors about COVID-19 pandemic that may cause panic. In West Bengal, Government has declared that all educational institutes will remain closed till 10th June, 2020. Studies in different parts of the world stated that even in normal time, depression, anxiety, stress among under graduate college students are high. Several reasons are there.

In this situation the researcher wanted to carry out the study to find out the condition of the Mental Health of the under Graduate Students of Nadia District in West Bengal during lockdown and how they are facing this pandemic situation.
\end{abstract}

Keywords: COVID 19 pandemic, lockdown, stress, mental health, students, West Bengal

\section{Introduction}

From past two decade the social media beheld a dispersed enhancement in quantity, quality and utility. Now a day's which is easily available through the development of technology, thereby opening a platform for discussion between social media and mental health of present era. From the dawn of internet and other social networking sites human resources of present world have become more social virtually but less practically. This virtual life is isolating present man from other fellow beings thereby affecting his health like - mental \& physical and overall balance. Onward usage of social networking site among teenagers of the present era is a matter of concern for the parents, society \& researchers, as there are always two sides (positive \& negative) of every mutation (Pantic,2014). The aim of present research is to explore the effect of social media on mental health of undergraduate students in West Bengal. To achieve said purpose, the researcher reviewed and synthesized available related literature. Literature tabulate so far reveals that younger generation operates impressibility. As a confronting population of the contemporary era, younger generation is experiencing embryonic stage of whole life and is at higher risk of momentous mental health problem. Younger generation of present era is acting as active users of social media which has bracing towards the problems of mental health (Barkur, et al). The present breakneck situation requires more responsive, to know connection between social media and mental health problems is just a kick off point. Exploring and understanding the means with the help of which social media is affecting mental health of present younger generation is succeeding step which can enlighten the connections which are at playing the crucial role among these variables of young generation.

COVID 19 first identified in December, 2019 at Wuhan, China. From there within few months almost the entire 
world was infected (Dong, et al). The state government of West Bengal declared that all educational institutes will remain closed till 10th June, 2020. The regular academic activities have stopped in West Bengal from 16th March, 2020. In such circumstances mental illness is quite common. Keeping this in mind organizations like WHO, WEF, ADAA, APA etc. issued guidelines to combat mental health issues in the time of COVID 19 epidemic. Entire world is fighting against Corona virus. People are also fighting against mental illness in their own way in this critical situation(WHO,2020). How actually the college students of Nadia district in West Bengal are feeling now and how Social media affect their mental health is the main theme of this research paper.

\subsection{Significance of the Present Study}

'During lockdown period office, industries, educational institutes will remain closed but the stars, the Moon, the Earth will not stop rotating, time will run, so life will move on' (Biswas N, 2020). The world is fighting against Corona virus. Things will come into order in near future. We need to fight another battle which is against mental illness. Now-a-days this is the most important issues in our life. WHO Director-General Dr Margaret Chan once said "The inclusion of no communicable diseases under the health goal is a historical turning point. Finally, these diseases are getting the attention they deserve'(who.int). Again as even during 'normal' days 'One-in-ten people around the world suffer from a mental health disorder' and 'The COVID-19 pandemic is an anxious and uncartstime' (WEF), the present situation creating an adverse effect on the entire human beings. The World Economic Forum also opined that 'Stuck indoors, worried about an uncertain future, concerned for your family or friends: the pandemic is a stressful situation for anyone to contend with' (weforum.org).The young students are full of energy. If they failed to release their energy then it may createan adverse effect on their mentality. If they were locked then there is a huge possibility of getting mentally unhealthy. The young students are the immediate future of the country. Mentally healthy citizen makes healthy society. During this epidemic and lockdown most of the people are feeling bored. This uncertain and isolated situation brings anxiety, panic, depression and stress among human beings. Mental health issue is neglected in Indian society. We need to address this issue with the entire world. This is the first time that the entire world is facing such a pandemic situation. As the college and university students are the immediate future, there issues must be addressed properly. In such situation the present study focuses on the condition of mental health among the college and university students of West Bengal, which is need of the hour.

\subsection{Review of Literature}

COVID 19 is a very recent pandemic. Researchers throughout the world are working on this field. Very little work has been done on the area of mental health during this pandemic.

Jung, S. J. and Jun, J.(2020) in their paper 'Mental Health and Psychological Intervention Amid COVID-19 Outbreak: Perspectives from South Korea' stated that 'amid the spread of COVID-19 in South Korea, psychological interventions are being performed in several aspects'. They opined that 'a public approach is needed to overcome common psychological barriers.'

Therefore, the establishment of a public system is crucial to verify the validity of information released by the media. Communities and mental health authorities should consistently make efforts to enhance social support systems and eliminate stigma of the disease. Building a targeted mental healthcare strategy for different population domains, including the quarantined and medical staff, would also be beneficial.

Dong, L. and Bouey, J.(2020) in their paper 'Public Mental Health Crisis during COVID-19Pandemic, China' stated that due to COVID 19 the people of China are going through some psychological problems. They have stated in the paper that "the National Health Commission of China released a notification on January 26, 2020, providing guiding principles of the emergency psychological crisis interventions to reduce the psychosocial effects of the COVID-19 outbreak. China has been implementing emergency psychological crisis interventions to reduce the negative psychosocial impact on public mental health, but challenges exist. Public mental health interventions should be formally integrated into public health preparedness and emergency response plans. It simply acknowledges that mental health of the people must be addressed properly during this critical time.

Xiang Y. T, Zhao Y. J, Liu Z. H, Li X. H, Zhao N, Cheung T and Ng C. H. (2020) in their research article 'The COVID-19 outbreak and psychiatric hospitals in China: managing challenges through mental health service reform' found that 'The consequences of mass quarantines to contain the spread of the viral epidemic have highlighted the challenges of delivering psychiatric care to chronic patients with serious mental illness living in the community.' The paper concluded by saying, the COVID-19 outbreak has raised numerous challenges for psychiatric hospitals in China to safely manage patients' major psychiatric disorders in addition to preventing and treating COVID-19. In addressing these challenges, future community mental health system reform is necessary to re-balance the system by 
re-distributing resources from hospital-centric services to community-based and primary care services. Lessons and experiences from previous bio-disasters such as SARS that have led to the strengthening of the public mental health system should be considered.

FiorilloA. And Gorwood P.(2020) in their paper 'The consequences of the COVID-19 pandemic on mental health and implications for clinical practice' stated that 'we will face an increase of mental health problems, behavioral disturbances, and substance-use disorders, as extreme stressors may exacerbate or induce psychiatric problems.' These findings suggest that minimizing disruption to work and social functioning, and increasing access to mental health services in the community, are important policy goals to minimize pandemic-related impacts on mental health and wellbeing. Innovative and creative strategies are needed to meet these community needs while continuing to enact vital public health strategies to control the spread of COVID-19. The researchers suggested some measures to reduce the intensity of mental illness an how to remain mentally healthy during COVID 19.

\subsection{Statement of the Problem}

The present research tries to explore the mental health condition of the college undergraduate regular mode students of Nadia district in West Bengal during COVID 19 and lockdown. Therefore the researcher considered the title of the problem as: 'The Impact of Social Media on Mental Health of Under Graduate Students of Nadia District in West Bengal'.

\section{Objective of the Study}

The major objectives of the present research are:

1. To find out the Mental Health condition of the Under Graduate College Students of Nadia district in west Bengal during COVID-19 Pandemic and Lockdown.

2. To find out how Under Graduate College Students are coping with the current situation.

\section{Delimitation of the Study}

West Bengal is a big state of India. There are twenty three districts in West Bengal. Due to shortage of time and unavailability of proper connection, Only Nadia district are including my present research paper.

\section{Methodology}

The present research work is an effort to describe the mental health condition of the undergraduate students of Nadia district in West Bengal. It is a survey based descriptive research. To capture the complexity of reality in its original form, with minute details and to understand the reality in a comprehensive and holistic way, Qualitative approach has been used. For better and clear understanding simple percentage and Graphical representation has also been used.

\subsection{Population}

The students those who are pursuing Undergraduate students from the government and government aided colleges of Nadia district in West Bengal in regular mode are the population in the present study. Others category students are excluded from the present study.

\subsection{Sample}

The sample contained 145 of different Undergraduate students of Nadia district in West Bengal. Students (Male - 75, Female- 70) are considered as the sample of the study of different place of the Nadia District. Also these samples are divided by rural and urban section.

- Area of Study: The Undergraduate College's students of Nadia District were selected from only in West Bengal.

- Gender: Both male and female students were includes in this study.

- Location: Both rural and urban students were includes in this study.

\subsection{Sampling Techniques}

Quota sampling are used for data collection of different areas of Nadia District. 


\subsection{Tools and Technique}

Keeping the objectives of the study in mind a questionnaire consisting of Ten open ended questions are made. Then the questionnaire is sent to an expert giving him the details of the research design for validating the questionnaire. After going through the research design the expert approved the questionnaire.

This questionnaire is then sent to the target participants using Google form through WhatsApp, Facebook messenger, Email with short information about the research. The researcher also assured the participants that the information and identity will remain confidential.

\subsection{Data Collection}

Data is collected from Nadia districts of West Bengal as planned. The students have sent their feedback through WhatsApp, Facebook messenger, Email etc.. The researcher also collected data from the participants over telephone as per the convenient time of the participant. These calls were recorded.

\subsection{Data Interpretation and Analysis}

After collecting the answer sheet and recordings, the raw data is systematically and intensively analyzed sentence by sentence and open coding is done in every reply sheet. Separate sheet has been prepared for the recorded data. After that, the key concepts are classified into different categories. And at last core category is formed by comparing the entire questionnaire cum reply sheet.

Interpretation and analysis has been done very carefully, keeping in mind about the objective of the present research. To know about how COVID- 19 pandemic affected the students and their family the following question was asked:

\section{1) How COVID 19 affected you and your family?}

i. $6.2 \%$ students (2.6\% Male and 3.6\% Female) feel that COVID 19 have not affected them or their family.

ii. 9.2\% students (4.1\% Male and 5.1\% Female) feel that COVID 19 affected them and their family positively. They feel that because of lockdown they have become more health conscious, more hygienic and they are fortunate to spent quality time with their family.

iii. $84.6 \%$ (40.1\% Male and 44.5\% Female) student's feel they have been affected largely negatively. While describing how they were affected they used terms like: Worried, Bored, Isolated, mentally broken, panicked, depressed, fear, scared, locked in, tension, anger, helplessness, uncertainty, hypertension, despair, shattered, anxious etc. The scariest things to the students are loss of income which means financially they are largely affected, medical services and academic progress.

There are some students those who are uncertain about the next meal. To know about how the students are feeling during COVID-19 pandemic and lockdown, the following question was asked:

\section{2) How you are feeling now?}

ii. No doubt that the time is not good. Unfortunately $45.7 \%$ students (17.5\% Male and $28.2 \%$ Female) cannot spend time in a positive way. They ae feeling extremely bored. To them, they are living their life as a criminal locked in jail. They think that life has stopped. Most of the time they sit alone in the house or at the roof and lay on bed alone. The percent of such students are quite alarming.

The next point that the researcher wanted to know is that do the students feel that their life has been changed, if so then what was the nature of the change and how this change affected their life. To explore this fact the following question was asked to the students:

\section{3) Do you think that now life has been changed? If so, how?}

i. $13.2 \%$ students ( $8.1 \%$ Male and 5.1\% Female) feel that there was no change in life because of COVID 19 .

ii.9.8\% students (2.7\% Male and 7.1\% Female) feel that because of COVID 19, life have changed in a positive way. Major reason behind thinking so is, most of the students think because of COVID 19 they are fortunate to have ample of time to do whatever they like. They can spend spent time with their loved family members, remembering the good old days, read story books, watch movies and so on. Most of the Guardians now a day are not creating any pressure on the students.

iii. $77 \%$ students (30.7\% Male and $46.3 \%$ Female) feel that Corona virus at present have completely ruined their life. It brought complete change in life. Students used the following words to describe their changed situation: life stopped, isolated, loneliness, uncertainty, financially ruined, locked in jail like situation, boredom, fear, destroyed 
happiness, end of the world feeling, insecurity, confused, hell, tension, panic, wastage of time, anxiety, depressed, and lazy.

How to cope with the changed situation is very important to stay mentally healthy. That is why, how the students handle the situation when they feel bad and stressed these information's are very crucial. To discover this area the following question was included in the questionnaire:

\section{4) If you don't feel good then what do you do?}

Most of the students (68.9\%, Male- $28.4 \%$ and Female- $40.5 \%)$ keep themselves busy with different things which are good and expected, but small numbers of students (14.6\%, Male- $6.6 \%$ and Female- $8 \%$ ) are there who do nothing but stay alone. The students do the following things to divert their mind:

Write diary, Engaged in spiritual thoughts, Offer prayer to god. Play game with family members and online/offline games. Also with pet., Watch movies, news, web series, comedy video clips dance programme etc, Engage in cooking, Talk to family members and friends., Connected through Social net working sites, Listening music and recitation, Help Mom or Dad in the house hold works, Gardening, Writing poetry and prose, Study or reading story books, Yoga, Sleep, Sit alone and meditate, Singing, Dancing, Drawing, Simply roam alone at roof, Photography, Knitting, Play musical instrument, See old album and live in that time.

These are the activities by which students divert their mind and relax themselves.

\section{Findings}

The findings of the study are:

i. $\quad 5.9 \%$ students (2.6\% Male and 3.3\% Female) feel that COVID 19 have not affected them or their family $8.9 \%$ students $(2.6 \%$ Male and $6.3 \%$ Female) feel that COVID 19 affected them and their family positively. $85.2 \%$ students $(44.1 \%$ Male and $41.1 \%$ Female) feel they and their family have been affected largely negatively.

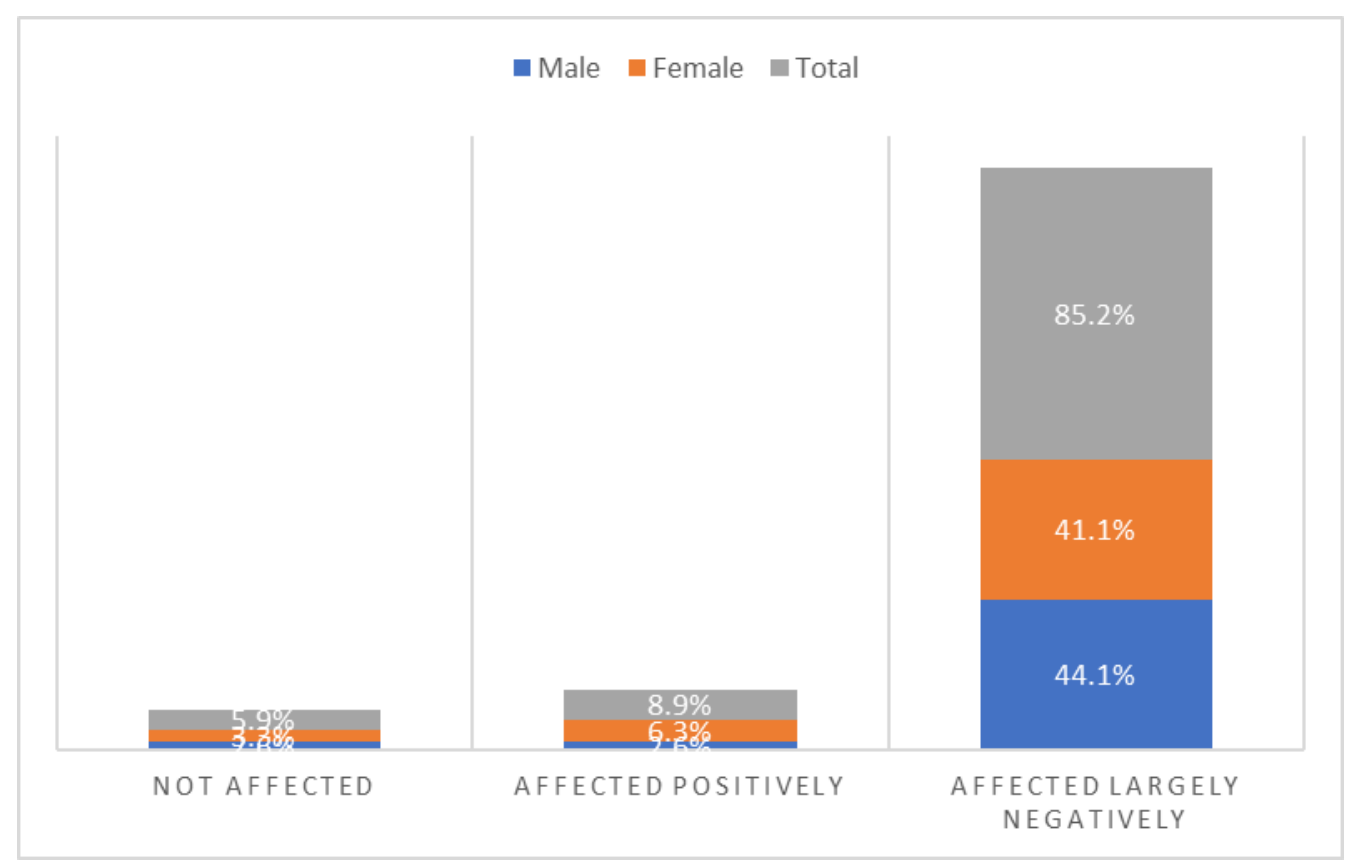

Figure 1. Opinion of Family Members Regarding Affect of COVID-19

ii. $\quad 4.8 \%(1.5 \%$ Male and 3.3\% Female) students feel that at this point of time they are feeling absolutely good. $26.1 \%$ (10.7\% Male and $15.4 \%$ Female) students feel that they have mixed feelings. Sometimes they are feeling good and sometimes they are feeling bad.69.1\% (37.9\% Male and 31.2\% Female) students feel that they are not feeling good at all. 


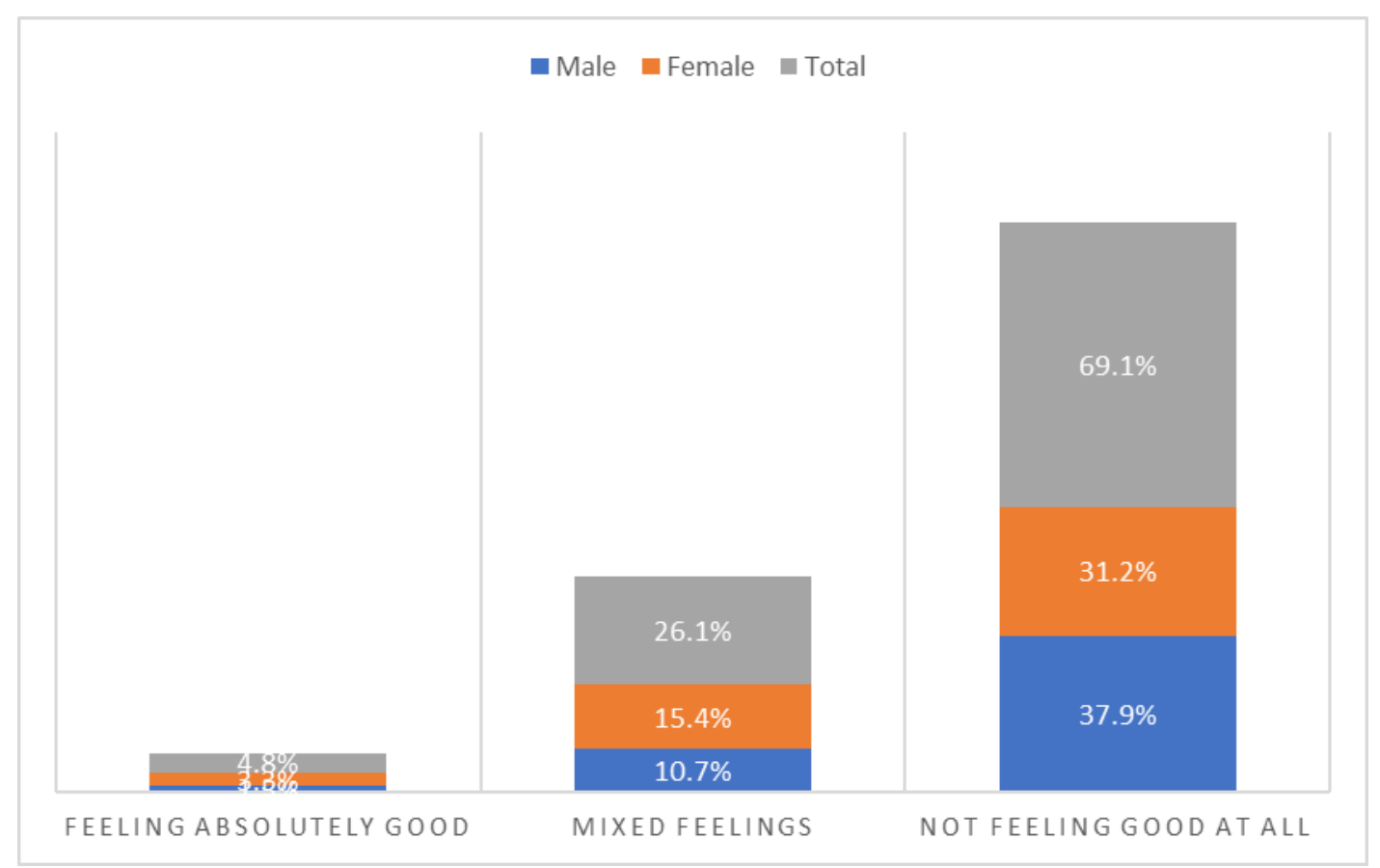

Figure 2. Opinion of People about COVID-19 Towards Pandemic Situation

iii. $\quad 82.7 \%$ students (44.5\& Male and $38.2 \%$ Female) spend time in a positive and creative way. $17.3 \%$ students (5.5\% Male and $11.8 \%$ Female) cannot spend time in a positive way. They feel extremely bored.

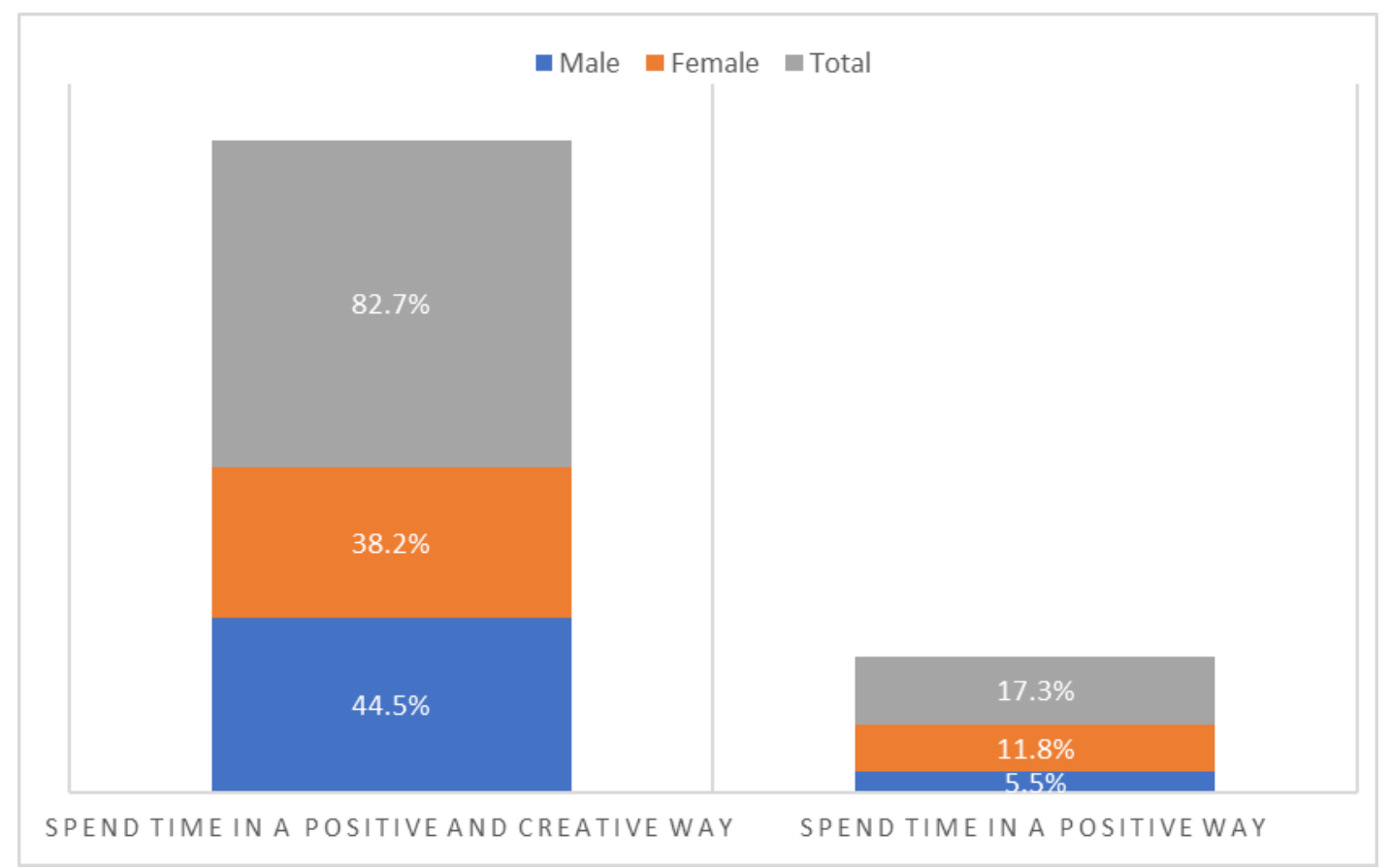

Figure 3. Opinion Regarding Way of Spending Time Towards COVID-19 Pandemic

iv. $4 \%$ students $(1.1 \%$ Male and $2.9 \%$ Female $)$ feel that there was no change in life because of COVID $19.10 \%$ students (2.2\% Male and $7.8 \%$ Female) feel that because of COVID 19, life have changed in a 
positive way $86 \%$ students $(46.7 \%$ Male and $39.3 \%$ Female) feel that Corona virus at present have completely ruined their life.

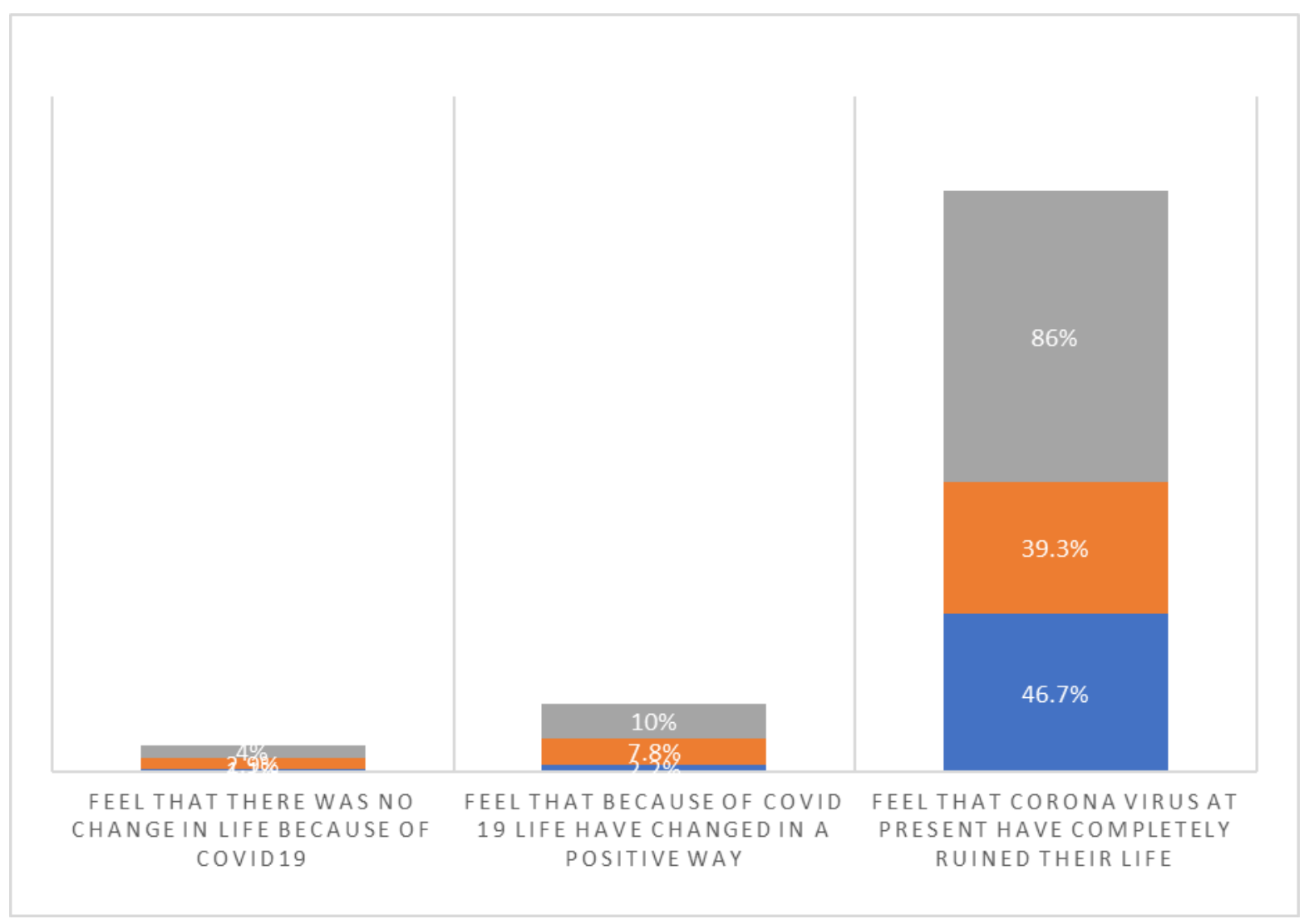

Figure 4. Opinion Regarding Change of life Pattern During COVID -19 Pandemic

v. $\quad 85.4 \%$ students ( $43.5 \%$ Male and $41.9 \%$ Female) are facing the critical situation in a positive way, keeping themselves busy with good activities. $14.6 \%$ students $(6.6 \%$ Male and $8 \%$ Female) are unable to face this critical situation positively.

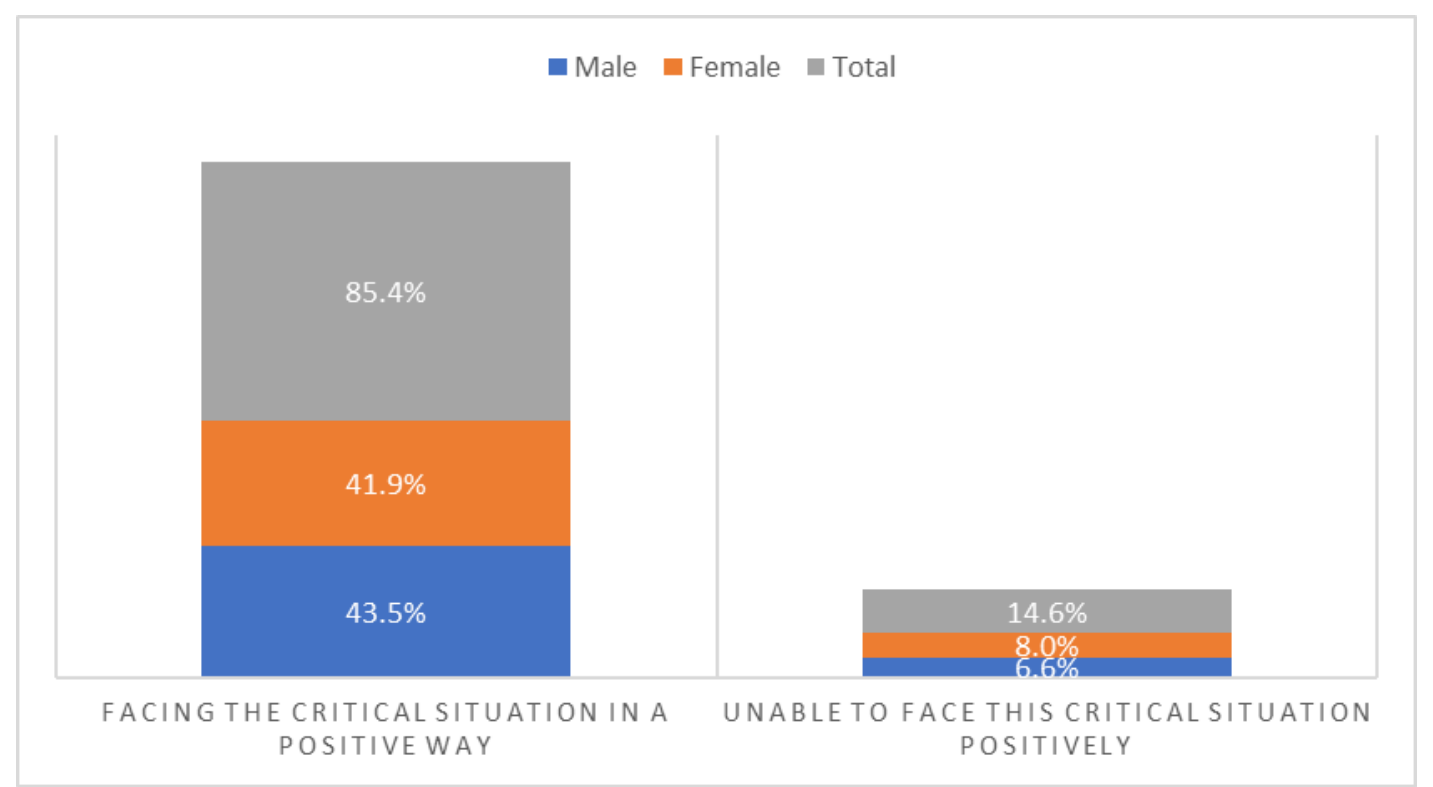

Figure 5. Opinion: Peoples Facing the Critical Situation in the Time of COVID-19 Pandemic 


\section{Conclusion}

From the findings of the research it is clear that huge number of students is going through a very critical time. The pandemic not only affected the students but it has also affected the most of the student's family brutally. COVID 19 pandemic and lockdown situation is affecting to mental health of the undergraduate students of West Bengal adversely. The female students are slightly in a better position. Amidst the gloomy environment the students consciously or unconsciously are fighting against the pandemic. Beside bitter truth, some glimmer of hope is also there. The students are not sitting idle and engulfed by loneliness and depression. Most of the students are busy with different interesting and creative work at the same time many of them are helping the poor, the downtrodden people during this hard time. They are not living only for themselves but for others also. It is giving them celesial joy. World economic Forum advised to stay connected with others, help and support others, look after ones physical wellbeing, proper sleep, manage difficult feelings, proper use of media, getting proper facts, proper daily routine, set goals, keeping mind in active mode, relax and doing those things which gives happiness, to remain mentally healthy (weforum.org). It is good to see that students of Nadia District of West Bengal in India have adopted all those things and additionally they have adopted something more to cope up with the situation.

It is also a matter of concern that Indian students are locked for almost twenty two days. Officially as per present order the lockdown will continue till 3rd May, 2020 (mygov.in). If things come under control then its fine otherwise if the government extends the lockdown period, then the students, parents and authority must be more conscious. It is a matter of concern that already more than $15 \%$ students are prone to mental illness. They are not spending time properly or engaging themselves in proper works. For those students proper counselling is very essential for their future life. Parents should look after their children more consciously and college or university or government authority must take proper action.

\section{References}

Barkur, G., \& Vibha, Kamath. B. G. (2020). Sentiment analysis of nationwide lockdown due to COVID 19 outbreak: Evidence from India. Asian Journal of Psychiatry, 51. https://doi.org/10.1016/j.ajp.2020.102089

Dong, L., \& Bouey, J. (2020). Public Mental Health Crisis during COVID-19 Pandemic, China. National library of medicine, 26(7), 1616-1618. https://doi.org/10.3201/eid2607.200407

Fiorillo A., \& Gorwood P. (2020). The consequences of the COVID-19 pandemic onmental health and implications for clinical practice. European Psychiatry, 63(1), e32,1-2. https://doi.org/10.1192/j.eurpsy.2020.35

Jung S. J., \& Jun J. (2020). Mental Health and Psychological Intervention Amid COVID-19 Outbreak: Perspectives from South Korea. YMJ. https://doi.org/10.3349/ymj.2020 .61.4.271

Mental health included in the UN Sustainable Development Goals. Retrieved from https://www.who.int/mental_health/SDGs/en/on 17/04/2021

Nigam, C. (2020, March 26). Covid-19 pandemic: Depression, anxiety go viral as nation observes lockdown, Retrieved from https://www.indiatoday.in

Whitley, R. (2020, March 19). Improving Student Mental Health During the COVID-19Crisis. Retrieved 12/04/2021 from https://www.psychologytoday.com/us/blog/talking-about-men/202003/improving-student-mental-health-duringthe-covid-19-crisis

World Health Organization (WHO). Mental health and psychosocial considerations during the COVID-19 outbreak. Retrieved 21/05/2021

from https://www.who.int/docs/default-source/coronaviruse/mental-health-considerations.pdf

Xiang Y. T, Zhao Y. J., Liu Z. H., Li X. H., Zhao N., Cheung T., \& Ng C. H. (2020). The COVID-19 outbreak and psychiatric hospitals in China: managing challenges through mental health service reform. International Journal of Biological Sciences, 16(10), 1741-1744. https://doi.org/10.7150/ijbs.45072 


\section{Copyrights}

Copyright for this article is retained by the author(s), with first publication rights granted to the journal.

This is an open-access article distributed under the terms and conditions of the Creative Commons Attribution license (http://creativecommons.org/licenses/by/4.0/). 